\title{
Binding of Cytokines to Pharmaceutically Prepared Human Immunoglobulin
}

\author{
Morten Svenson, Morten Bagge Hansen, and Klaus Bendtzen \\ Laboratory of Medical Immunology, Rigshospitalet University Hospital, DK-2200 Copenhagen, Denmark
}

\begin{abstract}
Pharmaceutically prepared IgG, pooled from sera of over 2,000 normal individuals, contained both monomeric and dimeric IgG. Each type of IgG bound ${ }^{125}$ I-labeled interleukin (IL)-1 $\alpha$, IL-1 $\beta$, IL-6, and tumor necrosis factor (TNF)- $\alpha$. Increased binding to IgG was observed if ${ }^{125} \mathrm{I}-\mathrm{IL}-1 \beta$ was denatured by heating to $39^{\circ} \mathrm{C}$. However, the binding of both nondenatured and denatured ${ }^{125} \mathrm{I}-\mathrm{IL}-1 \beta$ was not inhibited by unlabeled IL-1 $\beta$. In contrast, binding of ${ }^{125} \mathrm{I}-\mathrm{IL}-1 \alpha,{ }^{125} \mathrm{I}-\mathrm{IL}-6$, and ${ }^{125} \mathrm{I}-\mathrm{TNF} \alpha$ was inhibited by the corresponding unlabeled cytokine. Papain-digestion of IgG abolished binding of ${ }^{125}$ I-TNF $\alpha$ but failed to influence the displaceable binding of ${ }^{125} \mathrm{I}-\mathrm{IL}-1 \alpha$ and ${ }^{125} \mathrm{I}-\mathrm{IL}-6$. ${ }^{125}$ I-TNF $\alpha$ was a mixture of trimeric and monomeric forms, the latter being the predominant form at lower concentrations. The apparent saturability of ${ }^{125}$ I-TNF $\alpha$ was explained by a higher nonspecific binding of monomeric than of trimeric ${ }^{125}$ I-TNF $\alpha$ to IgG. The amounts of cytokine antibodies in IgG preparations would contribute $\sim 2 \mu \mathrm{g}$ anti-IL-1 $\alpha$ IgG and $1 \mu \mathrm{g}$ anti-IL-6 IgG per kg body wt during high dose immune globulin therapy. In conclusion, pharmaceutical preparations of human IgG contain specific and neutralizing, high affinity antibodies against IL-1 $\alpha$ and IL-6, but not against TNF $\alpha$ or IL-1 $\beta$. There are significant methodological pitfalls that hamper detection of IgG autoantibodies against cytokines. (J. Clin. Invest. 1993. 92:2533-2539.) Key words: human immune globulin, IgG • autoantibodies to cytokines $\bullet$ interleukin- $1 \alpha \cdot$ interleukin- 6 .
\end{abstract}

\section{Introduction}

Several reports have described the presence of antibodies against immunoinflammatory polypeptides (cytokines) in diseased as well as in healthy individuals (for review see reference 1). Since intravenous immunoglobulin therapy has been reported to be beneficial in more than 35 diseases with immunopathologic features (2), and because circulating cytokines may be involved in the clinical outcome of some of these diseases ( 3 , 4 ), it is conceivable that at least part of the observed clinical responses may relate to administration of naturally occurring antibodies to some of these cytokines.

Different assays have been used to measure these antibodies: Western blotting (5-10), competition in RIAs and ELISAs (11-14), binding in direct ELISAs $(8-10,15,16)$, binding of radiolabeled cytokines (12-14, 17-23), and biological interfer-

Address correspondence to Dr. Klaus Bendtzen, Laboratory of Medical Immunology, 7544 Rigshospitalet University Hospital, 20 Tagensvej, DK-2200 Copenhagen N, Denmark.

Received for publication 11 January 1993 and in revised form 16 June 1993.

J. Clin. Invest.

(c) The American Society for Clinical Investigation, Inc. $0021-9738 / 93 / 11 / 2533 / 07 \quad \$ 2.00$

Volume 92, November 1993, 2533-2539 ence assays $(7,8,10,15,17,24-27)$. However, other serum factors than antibodies may compete in RIAs and ELISAs, and inhibition of biological activities may be caused by many factors apart from neutralizing antibodies to cytokines (28-31). Judged by analyses of monoclonal antibodies there may not be a simple correlation between biological blocking and antibody reactivity in direct ELISAs or in Western blotting experiments, and detection of antibody binding may be sensitive or insensitive to minor alterations in, or denaturation of, the ligand (32, $33)$. Furthermore, it has recently been shown that different immunization procedures of rabbits using murine IL- $1 \beta$ resulted in production of antibodies that selectively reacted with nondenatured or denatured cytokine (34). It may therefore be argued that detection of antibodies against cytokines in humans should involve binding analysis to nondenatured and denatured forms of individual cytokines. In case of autoantibodies, ligand binding must be evaluated with regard to both saturable and nonsaturable binding, and the binding must take place at the Fab parts of the immunoglobulins.

To investigate this, we have analyzed the binding of the ${ }^{125}$ I-labeled recombinant human cytokines IL- $1 \alpha$, IL- $1 \beta$, IL-6, and TNF $\alpha$ to human IgG pharmaceutically prepared from the blood of healthy donors.

\section{Methods}

Six batches of human IgG (Nordimmun $\circledR$ ) from the sera of at least 2,000 healthy Danish adults per batch were kindly donated by Novo Nordisk (Bagsværd, Denmark). The IgG was pharmaceutically prepared by gentle precipitation with polyethylene glycol followed by ion exchange and contains no chemically or enzymatically modified immunoglobulins. Human recombinant interleukin 1 (IL-1) $\alpha$ and $-\beta$ were generous gifts from Dainippon (Osaka, Japan) and Novo-Nordisk (Gentofte, Denmark). Recombinant human tumor necrosis factor $\alpha$ (TNF $\alpha$ ) was a gift from Ernst Boehringer Institute (Vienna, Austria). Recombinant human interleukin 6 (IL-6) was donated by Amersham (Birkerød, Denmark ). ${ }^{125} \mathrm{I}-\mathrm{IL}-1 \alpha\left(2-3 \times 10^{5} \mathrm{cpm} / \mathrm{ng}\right),{ }^{125} \mathrm{I}-\mathrm{IL}-1 \beta(1-3$ $\left.\times 10^{5} \mathrm{cpm} / \mathrm{ng}\right),{ }^{125} \mathrm{I}-\mathrm{IL}-6\left(0.5-1 \times 10^{5} \mathrm{cpm} / \mathrm{ng}\right)$ and ${ }^{125} \mathrm{I}-\mathrm{TNF} \alpha(1-3 \times$ $10^{4} \mathrm{cpm} / \mathrm{ng}$ ) were kindly provided by Amersham. All radiolabeled cytokines bound specifically to cell receptors with preserved intrinsic activity: ${ }^{125} \mathrm{I}-\mathrm{IL}-1 \alpha$ and ${ }^{125} \mathrm{I}$-IL-1 $\beta$ were tested on EL4 cells (35), ${ }^{125} \mathrm{I}$-IL6 was tested on B9 cells (14), and ${ }^{125}$ I-TNF $\alpha$ was tested for cytotoxicity using WEHI 169 cells (36). Furthermore, molecular size chromatography of ${ }^{125} \mathrm{I}-\mathrm{IL}-1 \alpha$ and ${ }^{125} \mathrm{I}-\mathrm{IL}-1 \beta$ showed less than $10 \%$ aggregation after storage at $4^{\circ} \mathrm{C}$, whereas $15-20 \%$ of ${ }^{125} \mathrm{I}-\mathrm{IL}-6$ appeared as aggregates. Taken directly from the stock solution, more than $75 \%$ of ${ }^{125} \mathrm{I}-\mathrm{TNF} \alpha$ was on a trimeric form. Four different preparations of the ${ }^{125} \mathrm{I}$-labeled cytokines were tested with similar results.

Rabbit antibodies to the Fc parts of human IgG (code 424) were from Dako (Glostrup, Denmark). Magnetized polymer beads coated with donkey anti-rabbit antibody (Amerlex-M, code RPN 510) were purchased from Amersham. The detergents Triton X-100 and Tween 20 were from Sigma (St. Louis, MO) and Merck (Darmstadt, Germany), respectively. Skimmed milk (lipid content below $1 \%$ ) was purchased from a local supermarket.

Specific rabbit antiserum to human TNF $\alpha$ was obtained by repeated multiple-site intracutaneous injections of $10 \mu \mathrm{g}$ human recombinant TNF $\alpha$ into high-responder rabbits (6). The antigen was coupled 
with glutar aldehyde to diphtheria toxoid, added to Freund's incomplete adjuvant, and absorbed on $\mathrm{Al}(\mathrm{OH})_{3}$ before immunization. Specific rabbit antiserum to IL- $1 \beta$ was made similarly, except that human recombinant IL- $1 \beta$ was heated at $39^{\circ} \mathrm{C}$ for $18 \mathrm{~h}$ before being coupled to diphtheria toxoid. The resulting antiserum bound native and heattreated ${ }^{125}$ I-IL-1 $\beta$ without cross-reactivity between the two forms.

RIA of ${ }^{125}$ I-labeled IL-1 $\beta$ and TNF $\alpha$. The rabbit antisera were diluted in $20 \mathrm{mM}$ phosphate buffer, $125 \mathrm{mM} \mathrm{NaCl}, 0.1 \% \mathrm{NaN}_{3}, \mathrm{pH} 7.4$ (PBS), containing $2 \%$ BSA (Sigma). The antisera were incubated in PBS, containing $2 \% \mathrm{BSA}$, with the ${ }^{125} \mathrm{I}$-labeled cytokines for $3 \mathrm{~h}$ at $4^{\circ} \mathrm{C}$ and bound and free ligands were then separated by use of the AmerlexM separation system (Amersham).

Binding of ${ }^{125}$ I-labeled cytokines to human serum IgG and skimmed milk. IgG (Nordimmun ${ }^{8}$ ), and unlabeled and ${ }^{125}$ I-labeled cytokines were diluted in PBS with $2 \%$ BSA. Coincubation was performed at room temperature in $100 \mu \mathrm{l}$, containing 6,000 to $40,000 \mathrm{cpm}$ of ${ }^{125}$ I-labeled cytokine, with or without 200 times excess of corresponding unlabeled cytokine $(0.1-0.24 \mu \mathrm{g})$. Fifty percent binding of IL- $1 \alpha$ and IL- $1 \beta$ to IgG occurs within $5 \mathrm{~min}$ (37). For practical reasons, however, coincubation of IgG with IL- $1 \alpha$, IL-6, and IL- $1 \beta$ was carried out overnight $(18 \mathrm{~h})$. Heat denaturation of IL-1 $\beta$ was carried out at $39-40^{\circ} \mathrm{C}$ for $18 \mathrm{~h}$. Coincubation with TNF $\alpha$ was done for $72 \mathrm{~h}$ (see below). Binding of IgG to cytokines was either analyzed by molecular size chromatography or by second antibody precipitation. Saturation binding analyses with ${ }^{125}$ I-IL- $\alpha$ and ${ }^{125}$ I-IL-6 to individual batches of pooled human IgG were performed in the following way: PBS, 100 $\mu \mathrm{l}$, containing $2 \%$ BSA, $0,1 \%$ Triton X-100, $60 \mu \mathrm{g} \mathrm{IgG,} \mathrm{500-5,000} \mathrm{cpm}$ $(=2-20 \mathrm{pg})$ of ${ }^{125} \mathrm{I}-\mathrm{IL}-1 \alpha$ and variable amounts of IL- $1 \alpha$ were incubated for $18 \mathrm{~h}$ at $4^{\circ} \mathrm{C}$. Bound and free tracer were separated at $4^{\circ} \mathrm{C}$ on columns containing $500 \mu$ l of Protein G Sepharose CL-4B (Pharmacia, Uppsala, Sweden) with PBS and $0.005 \%$ (wt/vol) thiomersal as running buffer. The bound material was eluted with $100 \mathrm{mM}$ glycine- $\mathrm{HCl}$, pH 2.4. Unspecific binding was assessed in the presence of $200 \mathrm{ng}$ IL- $1 \alpha$ per $100 \mu$ l. Analysis of ${ }^{125}$ I-IL-6 was done similarly, except for the use of $0.3 \mathrm{mg}$ of IgG and $1,000-5,000 \mathrm{cpm}(10-50 \mathrm{pg})$ of ${ }^{125} \mathrm{I}-\mathrm{IL}-6$ with variable amounts of IL-6. Unspecific binding was assessed in the presence of $700 \mathrm{ng}$ IL- 6 per $100 \mu \mathrm{l}$. The results were expressed in pM and as $\mu$ mol cytokine bound per mol of IgG, calculated from a mol wt of 17.5 $\mathrm{kD}$ for IL-1 $\alpha, 20.3 \mathrm{kD}$ for IL-6, and $150 \mathrm{kD}$ for IgG.

Binding of cytokines to $4 \%$ skimmed milk was performed in parallel with the above experiments, using the same concentrations of ${ }^{125} \mathrm{I}$ labeled cytokines. The binding was assessed by molecular size chromatography as described below.

Chromatographic separation of IgG-cytokine preparations. All procedures were carried out at $4^{\circ} \mathrm{C}$. The elution profiles of ${ }^{125} \mathrm{I}$-TNF $\alpha$ coincubated with or without IgG (Nordimmun $®$ ) were determined by the use of a Sephadex G-100 superfine column $(0.9 \times 32 \mathrm{~cm}$; Pharmacia) at a flow rate of $3.4 \mathrm{ml} / \mathrm{h}$ with fraction collection every $12 \mathrm{~min}$. Separation of bound and free ${ }^{125}$ I-labeled IL- $1 \alpha$, IL- $1 \beta$, and IL- 6 was performed on columns containing $10 \mathrm{ml}$ of Sephadex G-75 superfine (Pharmacia). The eluting buffer was RPMI 1640 with $25 \mathrm{mM}$ Hepes (Gibco Biocult, Paisley, Scotland), containing 0.14\% BSA and $0.1 \%$ $\mathrm{NaN}_{3}, \mathrm{pH}$ 7.2. Separation of IgG (Nordimmun ${ }^{\circledR}$ ) was performed on a Sephacryl S200 superfine column $(1.6 \times 90 \mathrm{~cm}$; Pharmacia $)$ at a flow rate of $12 \mathrm{ml} / \mathrm{h}$. Repetitive samples of $22 \mathrm{mg} \mathrm{IgG}$ in $600 \mu \mathrm{l}$ PBS were applied. Selected fractions were pooled and concentrated in dialysis bags placed on polyethylene glycol 20,000 (Merck). The protein content was quantified by absorbance at $280 \mathrm{~nm}$, using a standard IgG preparation in PBS as reference.

Second antibody precipitation of IgG-cytokine complexes. The samples were placed on ice and a previously determined optimal concentration of rabbit anti-human $\mathrm{Fc} \gamma$ antibodies was added. After $10 \mathrm{~min}$, the samples were diluted 16 times in ice cold PBS, containing 2\% BSA, and centrifuged at $2,000 \mathrm{~g}$ for $15 \mathrm{~min}$ at $4^{\circ} \mathrm{C}$. The pellet activity and the total ${ }^{125}$ I-activity were determined with an error of $4 \%$ or less in a gamma counter (1272 CliniGamma, LKB, Wallac OY, Finland). There was no binding of labeled cytokine to anti-Fc $\gamma$ antibodies when coincubated on ice for $60 \mathrm{~min}$ followed by column chromatography.
Papain treatment of IgG. Purified IgG (Nordimmun®), $25 \mathrm{mg} / \mathrm{ml}$ in PBS, supplemented with $10 \mathrm{mM}$ L-cysteine and 2 mM EDTA, was incubated with $20 \mathrm{mg}$ papain-agarose (Sigma) under gentle agitation at $37^{\circ} \mathrm{C}$ for $18 \mathrm{~h}$. The digested IgG was then applied on a Sephadex G-75 superfine column (Pharmacia). Fractions from the void volume to samples containing molecules of molecular size $35 \mathrm{kD}$ were pooled and concentrated in a dialysis bag placed on polyethylene glycol 20,000 (Merck). The protein content was quantified by absorbence at $280 \mathrm{~nm}$.

\section{Results}

Binding of ${ }^{125}$ I-labeled human cytokines to serum IgG. As shown by others (38), the pooled human IgG preparation contained monomeric and dimeric IgG (Fig. 1). Fractions containing dimeric IgG or monomeric IgG were pooled for further use. As shown in Table I, dimeric IgG (I) and monomeric IgG (II) bound the ${ }^{125}$ I-labeled cytokines. The displaceable binding of ${ }^{125}$ I-IL-1 $\alpha$ and ${ }^{125}$ I-IL-6 was similar to dimeric, monomeric, and unseparated IgG. A higher total and displaceable binding of ${ }^{125} \mathrm{I}-\mathrm{TNF} \alpha$ was obtained with dimeric IgG. As shown in Table I, ${ }^{125} \mathrm{I}$-IL-1 $\beta$ also bound to human IgG. Heat denaturation of the cytokine increased its binding almost seven times, particularly to dimeric IgG. The binding of ${ }^{125}$ I-IL- $1 \beta$, however, could not be displaced by $2 \mu \mathrm{g} / \mathrm{ml}$ of unlabeled IL- $1 \beta$.

Binding of cytokines to papain-treated $\operatorname{Ig} G$. When comparing binding of cytokines to IgG before and after treatment of the antibody preparation with papain, more than $60 \%$ of the displaceable binding of ${ }^{125}$ I-labeled IL- $1 \alpha$ and IL- 6 was preserved (Table II). Papain-treated IgG retained less than $10 \%$ of the displaceable ${ }^{125} \mathrm{I}-\mathrm{TNF} \alpha$ binding. In contrast to ${ }^{125} \mathrm{I}-\mathrm{TNF} \alpha$ and heat-denatured ${ }^{125} \mathrm{I}-\mathrm{IL}-1 \beta,{ }^{125} \mathrm{I}-\mathrm{IL}-1 \alpha$ and ${ }^{125} \mathrm{I}-\mathrm{IL}-6$ bound exclusively to fragments which were not precipitated by rabbit anti-human $\mathrm{Fc} \gamma$ antibody (Table II).

Effect of detergents and milk proteins on the binding of cytokine to human IgG. The presence of skimmed milk together with the detergents Tween 20 and Triton X-100 reduced the binding to IgG of the ${ }^{125}$ I-cytokines and, as shown in Table III, only the displaceable amounts of ${ }^{125}$ I-IL-1 $\alpha$ and ${ }^{125}$ I-IL-6 were retained on the IgG. Furthermore, the displaceable amount of ${ }^{125}$ I-TNF $\alpha$ was reduced $4-10$ times by addition of milk proteins, depending upon the detergent in the assay buffer (Table III). Nondisplaceable binding of heat-denatured ${ }^{125}$ I-IL-1 $\beta$ to IgG was reduced almost 5 times.

Without detergent, the binding to $4 \%$ skimmed milk alone was $12 \%\left({ }^{125} \mathrm{I}-\mathrm{IL}-1 \alpha\right), 7 \%\left({ }^{125} \mathrm{I}-\mathrm{IL}-6\right), 25 \%\left({ }^{125} \mathrm{I}-\mathrm{TNF} \alpha\right)$, and $60 \%$ (denatured ${ }^{125} \mathrm{I}-\mathrm{IL}-1 \beta$ ). High ligand concentrations reduced the binding of ${ }^{125}$ I-TNF $\alpha$ only. Thus, skimmed milk did

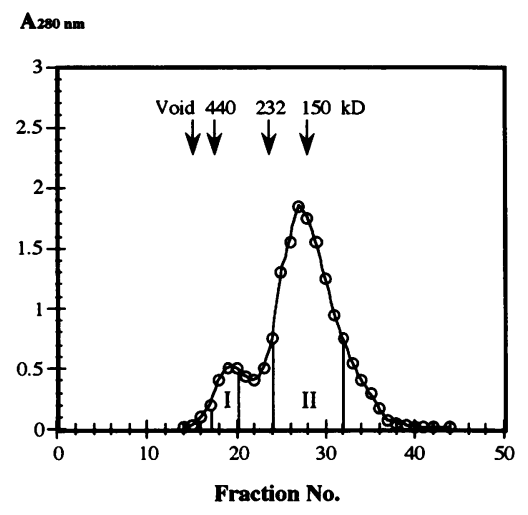

Figure 1. Sephacryl S200 molecular size elution profile of pooled human IgG (Nordimmun $\left.{ }^{\circledR}\right)$. Fractions in each of the marked areas of dimeric $(I)$ and monomeric (II) IgG were pooled and concentrated. 
Table I. Binding of ${ }^{125}$ I-labeled Human Cytokines to Sephacryl S200-fractionated, Pooled Human IgG

\begin{tabular}{|c|c|c|c|c|c|}
\hline \multirow[b]{2}{*}{ Cytokine } & \multicolumn{5}{|c|}{$\%$ binding } \\
\hline & IL-1 $\alpha$ & IL- & & IL-6 & $\mathrm{TNF} \alpha$ \\
\hline IgG: & & A & B & & \\
\hline dimeric (I) & $27(25)$ & $2(-0.5)$ & $14(1)$ & $20(8)$ & $12(7)$ \\
\hline monomeric (II) & $29(26)$ & & $7(0)$ & $16(7)$ & $8(4)$ \\
\hline unfractionated & $28(25)$ & $1.5(0.2)$ & $9(0)$ & $17(7)$ & $7(4)$ \\
\hline
\end{tabular}

Unfractionated dimeric and monomeric $\mathrm{IgG}, 3 \mathrm{mg} / \mathrm{ml}$ in PBS, were obtained by Sephacryl S200 chromatography (see Fig. 1). Binding was determined in triplicate as ${ }^{125} \mathrm{I}$-activity precipitated by rabbit anti-human $\mathrm{Fc} \gamma$ antibodies. Results are shown as mean values of $\mathrm{cpm}_{\text {bound }} / \mathrm{cpm}_{\text {total }} \times 100$; numbers in parentheses are

$\mathrm{cpm}_{\text {displaced with excess unlabeled cytokine/ }} / \mathrm{cpm}_{\text {total }} \times 100 .(A)$ non-heat treated traced and untraced IL-1 $\beta ;(B)$ heat-denatured traced and untraced IL-1 $\beta$.

not interfere with the binding of the cytokines to IgG by simple competition.

As shown in Table IV, the milk proteins also reduced binding of ${ }^{125} \mathrm{I}$-TNF $\alpha$ and ${ }^{125}$ I-IL- $1 \beta$ to their respective specific antibodies to a degree depending upon the structure of the ligand. However, this inhibition appeared to occur as a result of competitive binding to the milk molecules (Table IV).

Binding of ${ }^{125} I-T N F \alpha$ to pooled human $\mathrm{IgG}$. Binding of ${ }^{125} \mathrm{I}$-TNF $\alpha$ to IgG was carried out using $72 \mathrm{~h}$ of incubation before separation of bound and free ligand. This time of incubation was selected because molecular size separation of the tracer alone showed a time-dependent dissociation from an apparent trimeric to a monomeric form but with a stable distribution between the two forms after $72 \mathrm{~h}$ (data not shown). The distribution between the monomeric and trimeric structures of ${ }^{125} \mathrm{I}$-TNF $\alpha$ was also concentration-dependent. In contrast, the relative content of higher polymers of ${ }^{125}$ I-TNF $\alpha$ was not concentration-dependent (see Fig 2; void volume). Similar analyses using ${ }^{125} \mathrm{I}-\mathrm{IL}-1 \alpha,{ }^{125} \mathrm{I}-\mathrm{IL}-6$ as well as nondenatured and heatdenatured ${ }^{125} \mathrm{I}-\mathrm{IL}-1 \beta$ did not show a time- or concentration-dependent change in the distribution between the monomeric and polymeric forms of the cytokines.

Because of the concentration-dependent distribution of the monomeric and trimeric forms of ${ }^{125} \mathrm{I}-\mathrm{TNF} \alpha$, binding to $\mathrm{IgG}$ was calculated with regard to both forms of the cytokine:

Table II. Binding of Cytokines to Papain-treated IgG

\begin{tabular}{|c|c|c|c|c|}
\hline \multirow[b]{2}{*}{ Cytokine } & \multicolumn{4}{|c|}{ Preserved binding (\%) } \\
\hline & IL-1 $\alpha$ & IL-1 $\beta^{*}$ & IL-6 & TNF $\alpha$ \\
\hline \multicolumn{5}{|l|}{$\begin{array}{l}\text { Detection: } \\
\text { chromatography with }\end{array}$} \\
\hline $\begin{array}{l}\text { Sephadex G-100 } \\
\text { coprecipitation with rabbit }\end{array}$ & $76(86)$ & $17(\mathrm{nd})^{\ddagger}$ & $63(62)$ & $15(8)$ \\
\hline anti-human $\mathrm{Fc} \gamma$ antibody & $11(2)$ & $14(\mathrm{nd})^{\ddagger}$ & $17(8)$ & $12(5)$ \\
\hline
\end{tabular}

$\operatorname{IgG}$ (Nordimmun $\left.{ }^{\circledR}\right), 6 \mathrm{mg} / \mathrm{ml}$ in PBS, was pretreated with or without (control) papain. The effect is expressed as mean preserved binding of total bound ${ }^{125} \mathrm{I}(n=3)$; the preserved displaceable binding is shown in parentheses. ${ }^{*}$ Heat-denatured; ${ }^{*}$ nd: not detected.
Table III. Influence of Detergents and Skimmed Milk on the Binding of Cytokines to IgG

\begin{tabular}{|c|c|c|c|c|c|}
\hline \multirow[b]{2}{*}{ Cytokine } & & \multicolumn{4}{|c|}{$\%$ binding } \\
\hline & & IL-1 $\alpha$ & $\mathrm{IL}-1 \beta^{*}$ & IL-6 & TNF $\alpha$ \\
\hline & $\%$ milk & & & & \\
\hline \multirow[t]{2}{*}{$2 \%$ BSA } & - & $49(41)$ & $20(-1)$ & $29(6.0)$ & $12(7)$ \\
\hline & + & $44(40)$ & $4(0.2)$ & $11(6.7)$ & $3(1)$ \\
\hline $2 \%$ BSA & - & & $16(1)$ & & $13(8)$ \\
\hline$+1 \%$ Tween 20 & + & & $3(0.2)$ & & $5(2)$ \\
\hline $2 \% \mathrm{BSA}$ & - & $55(37)$ & $26(-1)$ & $12(6.7)$ & $30(22)$ \\
\hline$+0.1 \%$ Triton $\mathrm{X}-100$ & + & $43(38)$ & $5(0.5)$ & $9(6.3)$ & $5(2)$ \\
\hline
\end{tabular}

Human IgG (Nordimmun $\left.{ }^{\circledR}\right), 6 \mathrm{mg} / \mathrm{ml}$, was preincubated for $2 \mathrm{~h}$ in PBS with the additives indicated. The preparations were then incubated with labeled and with or without excess unlabeled cytokine. Binding of ${ }^{125} \mathrm{I}$-labeled cytokines to IgG was detected by coprecipitation with rabbit anti-human Fc $\gamma$ antibodies. Determinations were done in triplicate, and the results are shown as in Table I.

${ }^{*}$ Heat-denatured traced and untraced IL- $1 \beta$.

$\mathrm{cpm}_{\text {bound }} / \mathrm{cpm}_{\text {free }}=(a-b) \times \mathrm{cpm}_{\text {monomer }} / \mathrm{cpm}_{\text {free }}+b$,

where $\mathrm{cpm}_{\text {bound }}=a \times \mathrm{cpm}_{\text {monomer }}+b \times \mathrm{cpm}_{\text {trimer }}$

and $\mathrm{cpm}_{\text {free }}=\mathrm{cpm}_{\text {monomer }}+\mathrm{cpm}_{\text {trimer }}$

As shown in Fig. 3, a highly significant linear correlation was obtained by plotting $\mathrm{cpm}_{\text {bound }} / \mathrm{cpm}_{\text {free }}$ against $\mathrm{cpm}_{\text {monomer }} /$ $\mathrm{cpm}_{\text {free. }}$. This is obtained if $a$ and $b$ in the above equations are constants. Hence, it can be estimated from Fig. 3, that monomeric ${ }^{125} \mathrm{I}-\mathrm{TNF} \alpha$ exhibits more than 50 times higher nonspecific binding to IgG than trimeric ${ }^{125} \mathrm{I}-\mathrm{TNF} \alpha$.

Individual batches of pooled human IgG bind $I L-1 \alpha$ and $I L-6$ with high avidity. The equilibrium binding of IL- $1 \alpha$ and IL-6 to a pool of human IgG as functions of the free ligand concentrations is shown in Fig. 4. IL- $1 \alpha$ bound with an estimated average affinity (Kav) of 10 pM, whereas Kav for IL-6

Table IV. Skimmed Milk Suppresses Binding of ${ }^{125}$ I-labeled $T N F \alpha$ and $I L-1 \beta$ to Specific Heterologous Antibodies

\begin{tabular}{|c|c|c|c|c|}
\hline \multirow{3}{*}{ Skimmed milk } & \multicolumn{4}{|c|}{$\%$ suppression } \\
\hline & \multicolumn{2}{|c|}{ IL- $1 \beta$} & \multicolumn{2}{|c|}{$\mathrm{TNF} \alpha$} \\
\hline & A & B & $\mathrm{C}$ & D \\
\hline $1 \%$ & $4(3)$ & $30(27)$ & 7 & 35 \\
\hline $4 \%$ & $6(4)$ & $64(50)$ & 10 & 45 \\
\hline
\end{tabular}

Specific rabbit antibodies against human TNF $\alpha$ and IL-1 $\beta$ were used. To obtain different relative amounts of monomeric ${ }^{125} \mathrm{I}-\mathrm{TNF} \alpha$, the tracer was either taken directly from the stock solution $(C)$ or preincubated for $72 \mathrm{~h}$ at $10,000 \mathrm{cpm} / 100 \mu \mathrm{l}(D)$ (see Fig. 2). The tracer concentration during the binding assay was $4,000 \mathrm{cpm} / 100 \mu \mathrm{l}$. Without milk, $69 \%$ of the control and $55 \%$ of the preincubated ${ }^{125}$ I-TNF $\alpha$ bound to the antibodies. The rabbit anti-IL- $1 \beta$ antibodies bound $43 \%$ and $50 \%$ at $5,000 \mathrm{cpm} / 100 \mu \mathrm{l}$ of nontreated $(A)$ and heat-treated $(B)$ ${ }^{125}$ I-IL-1 $\beta$, respectively. The tracer solution was preincubated with milk for $2 \mathrm{~h}$ before addition of antibodies. Mean values of triplicate determinations. Values in parentheses: binding of ${ }^{125} \mathrm{I}-\mathrm{IL}-1 \beta$ before addition of antibodies. Results are derived from Sephadex G-75 chromatographic separations. 
$\%$

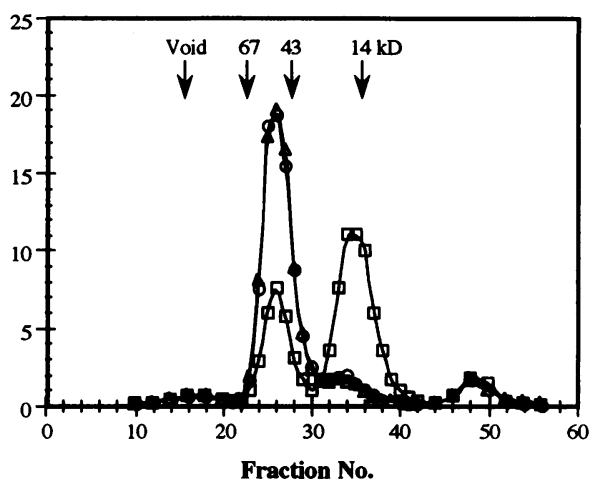

Figure 2. Elution profiles of ${ }^{125} \mathrm{I}-\mathrm{TNF} \alpha$ at different concentrations and after preincubation at room temperature. ${ }^{125} \mathrm{I}-\mathrm{TNF} \alpha, 3 \mu \mathrm{g} / \mathrm{ml}$ stock tracer solution, was diluted to $5 \mathrm{ng} / \mathrm{ml}$ in PBS, supplemented with $2 \% \mathrm{BSA} ; 150 \mu \mathrm{l}$ was then applied on a Sephadex G-100 column at $4^{\circ} \mathrm{C}$ after $2 \mathrm{~h}(0)$ and after $72 \mathrm{~h}$ of preincubation (口). ${ }^{125} \mathrm{I}-\mathrm{TNF} \alpha, 5$ $\mathrm{ng} / \mathrm{ml}$, preincubated with $2.5 \mu \mathrm{g} / \mathrm{ml}$ of TNF $\alpha$ for $72 \mathrm{~h}$ was also tested $(\Delta)$. The recoveries of tracer in the column runs exceeded $95 \%$.

was $80 \mathrm{pM}$. In addition, the binding capacity ( $\mathrm{Bmax}$ ) of this IgG preparation was three times higher for IL- $1 \alpha$ than for IL-6 ( $1.2 \mu \mathrm{mol} / \mathrm{mol} \mathrm{IgG} \mathrm{vs.} 0.38 \mu \mathrm{mol} / \mathrm{mol} \mathrm{IgG}$ ).

The different batches of pooled human IgG were almost identical with regard to IL- $1 \alpha$ binding. In contrast, the Kav and, to a lesser extent, Bmax of the binding to IL-6 varied considerably between the IgG preparations (Table V). There was no cross-binding between IL- $1 \alpha$ and IL-6 to the IgG preparations. Thus, $1 \mathrm{mg}$ of the different batches of $\mathrm{IgG}$ contained 0.6-0.9 ng anti-IL-1 $\alpha$ IgG and 0.2-0.4 ng anti-IL-6 IgG. Assuming that high-dose immune globulin therapy would contribute approximately $10 \mathrm{mg} / \mathrm{ml}$ to the preexisting level of $\mathrm{IgG}$ and noncooperative, single-site binding of the cytokines to $\operatorname{IgG}(2)$, the infused immunoglobulin would bind approximately $80 \%$ of IL- $1 \alpha$ and $20-70 \%$ of IL-6 at a ligand concentration of 1 $\mathrm{ng} / \mathrm{ml}$ (Fig. 5).

\section{Discussion}

A number of reports have appeared describing naturally occurring human antibodies against cytokines (5-8, 10-25, 27).

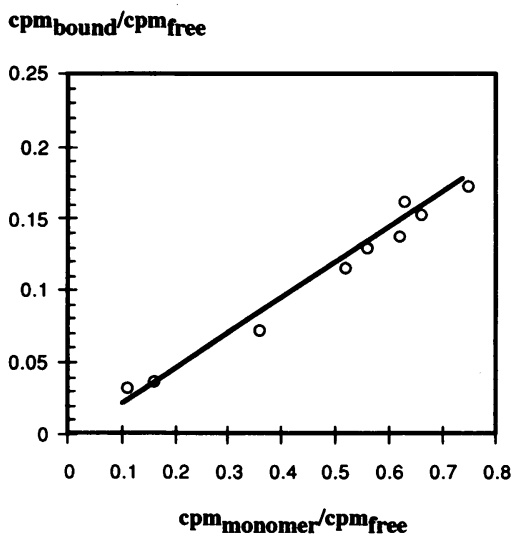

Figure 3. ${ }^{125} \mathrm{I}-\mathrm{TNF} \alpha$ binding to human IgG. IgG, $15 \mathrm{mg} / \mathrm{ml}$ PBS with $2 \%$ BSA, was incubated with $3 \mathrm{ng} / \mathrm{ml}$ to $2.5 \mu \mathrm{g} / \mathrm{ml}$ of ${ }^{125} \mathrm{I}-\mathrm{TNF} \alpha$ for $72 \mathrm{~h}$ at room temperature; $150 \mu \mathrm{l}$ was applied on a Sephadex G-100 column at $4^{\circ} \mathrm{C}$. The void volume cpm and the cpm distributed in the monomeric and trimeric pooled fractions of the ${ }^{125} \mathrm{I}-\mathrm{TNF} \alpha$ elution profile (see Fig. 2 ) were calculated. The recoveries of tracer in the column runs exceeded $95 \%$. $\mathrm{Cpm}_{\text {bound }}$ was calculated after subtraction of the void volume cpm of the tracer alone. The values were plotted as described in the text. Correlation coefficient $=0.98$.
Binding of IL-1 $\alpha$ to IgG $(\mu \mathrm{mol} / \mathrm{mol})$

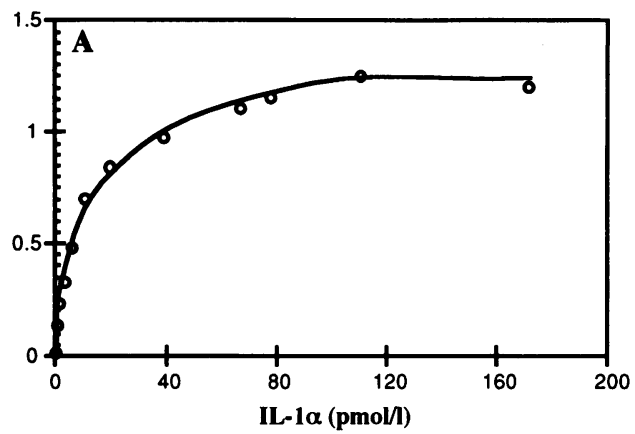

Binding of IL-6 to IgG ( $\mu \mathrm{mol} / \mathrm{mol})$

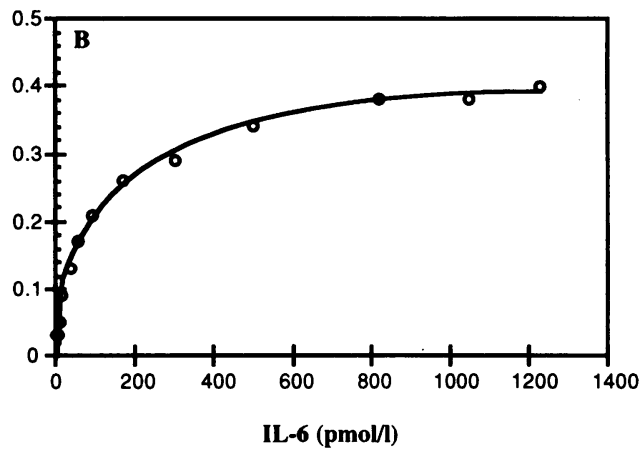

Figure 4. Equilibrium saturation binding of IL-1 $\alpha$ and IL-6 to human IgG. Specific binding is shown as total minus nonspecific binding of duplicate determinations. Binding capacity $\left(B_{\max }\right)$ was estimated from the plateau of the curve and the average affinity $\left(K_{\mathrm{av}}\right)$ as the free ligand concentration at $50 \%$ of $B_{\max }$. (A) IL- $1 \alpha ; K_{\mathrm{av}}=10 \mathrm{pmol} / \mathrm{liter}$ : $B_{\max }=1.2 \mu \mathrm{mol} / \mathrm{mol}$. ( $\left.B\right)$ IL-6; $K_{\mathrm{av}}=80 \mathrm{pmol} /$ liter: $B_{\max }=0.38$ $\mu \mathrm{mol} / \mathrm{mol}$.

Some of these antibodies seem to occur relatively frequently even in apparently healthy individuals; see ref. (1). Thus, serum IgG directed against TNF $\alpha$ and IL- $1 \alpha$ have been reported in $0-40 \%$ and in $1-30 \%$ of normal individuals, respectively, $(5,6,9,20-23)$. Recently, IgG specific for IL-6 were found in $15 \%$ of sera from Danish blood donors (14).

Saturation binding analysis is a necessary prerequisite if the presence of autoantibodies is being evaluated. In this regard,

Table V. IL-1 $\alpha$ and IL-6 Binding to Individual Preparations of Pooled IgG

\begin{tabular}{cccccc}
\hline & \multicolumn{3}{c}{ IL-1 $\alpha$} & & \multicolumn{2}{c}{ IL-6 } \\
\cline { 2 - 3 } \cline { 5 - 6 } $\begin{array}{c}\text { IgG } \\
\text { batch no. }\end{array}$ & $K_{\mathrm{av}}$ & $B_{\max }$ & & $K_{\mathrm{av}}$ & $B_{\max }$ \\
\hline & $p m o l / l i t e r$ & $\mu \mathrm{mol} / \mathrm{mol}$ & & $p m o l / l i t e r$ & $\mu \mathrm{mol} / \mathrm{mol}$ \\
& 10 & 1.2 & & 80 & 0.38 \\
1 & 12 & 1.5 & & 90 & 0.55 \\
2 & 10 & 1.3 & & 10 & 0.81 \\
3 & 14 & 1.6 & & 10 & 0.73 \\
4 & 10 & 1.8 & & 80 & 0.59 \\
5 & 10 & 1.6 & & 50 & 0.53 \\
6 & & & &
\end{tabular}

Six individual batches of Nordimmun $®$ were tested for binding of IL- $1 \alpha$ and IL-6 as described in Fig. 4. 


\section{$\mathrm{B} / \mathrm{T}(\%)$}

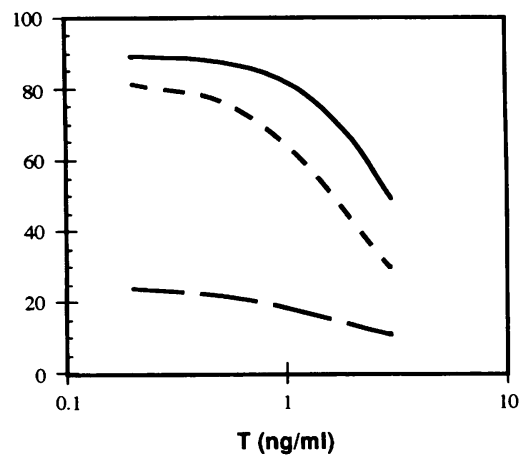

Figure 5. Estimated binding of IL- $1 \alpha$ and IL-6 to $10 \mathrm{mg} / \mathrm{ml}$ of different batches of human IgG. Calculations were carried out using the formulas:

$$
B / F=\frac{B_{\max }}{K_{\mathrm{av}}+F} \text { and } T=B+F
$$

where $B \quad$ is the concentration of bound ligand;

$F \quad$ is the concentration of free ligand;

$T$ is the total concentration of the ligand;

$B_{\max }$ is the total concentration of binding sites; and

$K_{\mathrm{av}}$ is the average affinity.

(-) IL-1 $\alpha$, batch 3 , see Table V; (- - IL-6, batch 1, see Table V; and (- - ) IL-6, batch 3 , see Table V.

direct ELISA and Western blotting assays have limited use compared with binding analyses using ${ }^{125} \mathrm{I}$-labeled cytokines in solution. This relates to the amount and state of denaturation of the fixed molecules and to possible differences in the binding properties of fixed and dissolved cytokine $(32,39)$.

In accordance with previous results using sera of normal individuals $(13,14,19,20)$, we found evidence of autoantibodies directed against IL- $1 \alpha$ and IL- 6 in all of six human IgG preparations manufactured for clinical use. Hence, the binding of these cytokines was saturable and selectively occurred to the Fab fragments of the IgG molecules. Also, the binding affinities of these antibodies were in the same range as those previously detected for IgG in individual human sera $(20,35)$.

Pools of human immune globulin have been shown to contain dimeric IgG, which has been proposed to constitute idiotype-anti-idiotype pairs $(38,40)$. However, compared with unfractionated and monomeric IgG, dimeric IgG did not differ in their specific binding of ${ }^{125} \mathrm{I}-\mathrm{IL}-1 \alpha$ and ${ }^{125} \mathrm{I}-\mathrm{IL}-6$, indicating the absence of appreciable amounts of blocking anti-idiotype antibodies. This is supported by the observation that individual sera failed to block ${ }^{125} \mathrm{I}-\mathrm{IL}-1 \alpha$ binding to a known amount of added human IL- $1 \alpha$ antibodies; our unpublished findings, for reviews see reference 21 .

Nonspecific binding may be reduced by the use of detergents (41), and milk proteins have been proposed to be superior to other proteins in blocking nonspecific binding of IgG in solid phase assay systems (42). Accordingly, skimmed milk reduced the nonspecific binding of both ${ }^{125} \mathrm{I}$-IL- $\alpha$ and ${ }^{125} \mathrm{I}$-IL6 ; the detergent Triton X-100 reduced only nonspecific binding of the latter. ${ }^{125} \mathrm{I}-\mathrm{IL}-\beta$ exhibited low and nonsaturable binding to IgG. Heat denaturation of ${ }^{125} \mathrm{I}-\mathrm{IL}-1 \beta$ increased only the nonspecific binding, and milk proteins suppressed the binding of the cytokine. From the analyses of individual sera, we and others have not been able to obtain evidence of antibodies of the IgG class directed against nondenatured IL-1 $\beta$ (19-21). Our data further indicate that IgG specific for denatured IL-1 $\beta$ occur rarely, if at all, in sera of healthy humans.

The existence of natural IgG directed against TNF $\alpha$ in hu- mans has been questioned recently on the basis of Western blot analyses (9). We found that binding of ${ }^{125} \mathrm{I}-\mathrm{TNF} \alpha$ to pooled human IgG was inhibited by excess amounts of unlabeled TNF $\alpha$. However, papain-treated IgG retained less than $10 \%$ of the displaceable binding of ${ }^{125} \mathrm{I}-\mathrm{TNF} \alpha$ and more than $50 \%$ was recovered by coprecipitation with anti-Fc $\gamma$ antibodies. Furthermore, skimmed milk suppressed the binding of ${ }^{125}$ I-TNF $\alpha$ to IgG more strongly than explained by simple, competitive binding of the ligand to milk. Therefore, the occurrence of natural antibodies against TNF $\alpha$ in pooled human IgG and, consequently, a frequent occurrence in normal human serum is questionable.

Different structural forms of human TNF $\alpha$ have been described. For example, $x$-ray analysis shows that crystalline TNF $\alpha$ is a trimer (43). Furthermore, monomeric, dimeric, trimeric, and higher polymeric forms have been found when examining TNF $\alpha$ in aqueous solution and biological fluids (44, 45 ). Using molecular size chromatography with recoveries exceeding $95 \%$, we did not observe an increased formation of higher polymers at low concentrations of ${ }^{125} \mathrm{I}-\mathrm{TNF} \alpha$ as observed by others (44). However, ${ }^{125} \mathrm{I}-\mathrm{TNF} \alpha$ appeared to exist on both a trimeric and monomeric form. The relative distribution between these molecular forms was dependent upon the concentration of the cytokine with a relative dominance of the monomeric form at lower concentrations.

The analyses of the binding of IgG to monomeric as well as trimeric ${ }^{125} \mathrm{I}$-TNF $\alpha$ suggest that the displaceable binding of ${ }^{125} \mathrm{I}$ TNF $\alpha$ was caused by a higher nonspecific binding of monomeric ${ }^{125} \mathrm{I}-\mathrm{TNF} \alpha$ to the immunoglobulins. Thus, the higher displaceable binding of ${ }^{125} \mathrm{I}-\mathrm{TNF} \alpha$ obtained with dimeric IgG may be explained by an increased nonspecific binding of TNF $\alpha$ to this IgG structure.

The results of the present study show the importance of saturation binding analysis and the demonstration of selective binding to Fab fragments when searching for autoantibodies to cytokines. To avoid misinterpretations, the presence of different structural forms of the ligand should be evaluated. Thus, different forms of the cytokine may exhibit different binding to antibodies, as illustrated here by the binding of nondenatured and heat-denatured ${ }^{125} \mathrm{I}-\mathrm{IL}-1 \beta$ and monomeric/trimeric ${ }^{125} \mathrm{I}$ TNF $\alpha$ to IgG.

Reduction of nonspecific binding to antibodies is of obvious importance and may be obtained by adding detergents or, more efficaciously, milk proteins. The latter was the only additive capable of reducing nonspecific binding to $\operatorname{IgG}$ of all the ${ }^{125}$ I-labeled cytokines. However, depending upon the structural form of the cytokine, milk proteins may also reduce the specific binding to antibody. Analysis of ligand binding to milk proteins may therefore help select the proper amount of these proteins for use in assays designed to evaluate specific binding of cytokines to naturally occurring or induced antibodies to cytokines.

IL- $1 \alpha$ and IL- 6 are biologically active at concentrations below $0.1 \mathrm{ng} / \mathrm{ml}$, and the circulating levels of the cytokines are generally below this concentration (3). However, during gramnegative sepsis or active stages of some immunoinflammatory diseases, blood levels of IL- $1 \alpha$ and IL- 6 increase considerably; however, the levels of IL- $\alpha$ and IL- 6 rarely exceed $0.5 \mathrm{ng} / \mathrm{ml}$ and $2 \mathrm{ng} / \mathrm{ml}$, respectively, although very high levels of IL-6 (up to more than $100 \mathrm{ng} / \mathrm{ml}$ ) may be seen in patients with septic shock $(3,46-49)$. Both cytokines are thought to be crucially involved in the pathology of sepsis $(3,4)$. 
Naturally occurring autoantibodies to IL- $1 \alpha$ and IL-6 in humans effectively neutralize the bioactivities of these cytokines in vitro $(14,35)$. A dose of $400 \mathrm{mg} / \mathrm{kg}$ per d on 5 consecutive $\mathrm{d}$ of the $\mathrm{IgG}$ preparations examined in this study would contribute approximately $2 \mu \mathrm{g}$ of anti-IL- $1 \alpha \mathrm{IgG}$ and $1 \mu \mathrm{g}$ of anti-IL-6 IgG per kg body wt. Even though these quantities are 2-3 orders of magnitude lower than those of monoclonal antibodies needed to suppress functions of cytokines in animals $(50,51)$, the exquisite binding affinities of the autoantibodies would provide a neutralizing capacity similar to that of monoclonals used in animals. For example, Jesmok et al. found significant protective effect of $150 \mu \mathrm{g} / \mathrm{kg}$ of monoclonal antibody to human TNF $\alpha$ in $E$. coli-challenged swine, and $100 \mathrm{ng} / \mathrm{ml}$ antibody was required for notable neutralization of TNF $\alpha$ found in the plasma of untreated septic pigs (mean plasma concentration: $2.5 \mathrm{ng} / \mathrm{ml}$ of TNF $\alpha$; reference 51 ). In comparison, high-dose IgG therapy would contribute about $10 \mathrm{mg} / \mathrm{ml}$ to the plasma concentration of IgG; this would provide approximately $10 \mathrm{ng} / \mathrm{ml}$ of specific antibody to IL- $1 \alpha$ capable of binding 1-2 $\mathrm{ng} / \mathrm{ml}$ of the cytokine.

It should be noted that IL- $1 \alpha$ is predominantly found in the membrane of antigen-presenting cells (52), and because IL- $1 \alpha$ as well as IL-6 are bound to surface receptors on responder cells such as lymphocytes (1), very low concentrations of $\operatorname{IgG}_{1}$ and $\mathrm{IgG}_{2}$ autoantibodies may trigger complement-mediated cytotoxic processes against these cells. Therefore, the presence of these autoantibodies in pharmaceutically prepared IgG may help to explain why high dose IgG therapy is beneficial in a number of pathogenetically obscure immunoinflammatory disorders.

\section{Acknowledgments}

Ms Susanne Meldgaard is thanked for excellent technical assistance. Amersham International generously supplied the radioiodinated cytokines. We are grateful to T. Tsuboi, K. R. Hejnæs, G. R. Adolf, and Amersham Denmark for kind gifts of recombinant human cytokines.

This study was supported by the Danish Blood Donor Foundation, the Danish Rheumatism Association, the Danish Medical Research Council, and the Danish Biotechnology Program.

\section{References}

1. Bendtzen, K., M. Svenson, V. Jønsson, and E. Hippe. 1990. Autoantibodies to cytokines-friends or foes? Immunol. Today. 11:167-169.

2. Dwyer, J. M. 1992. Manipulating the immune system with immune globulin. N. Engl. J. Med. 326:107-116.

3. Dinarello, C. A. 1991. Interleukin-1 and interleukin-1 antagonism. Blood. 77:1627-1652.

4. Billiau, A., and F. Vandekerckhove. 1991. Cytokines and their interactions with other inflammatory mediators in the pathogenesis of sepsis and septic shock. Eur. J. Clin. Invest. 21:559-573.

5. Jeffes, E. W. B., E. K. Ininns, K. L. Schmitz, R. S. Yamamoto, C. A. Dett, and G. A. Granger. 1989. The presence of antibodies to lymphotoxin and tumor necrosis factor in normal serum. Arthritis Rheum. 32:1148-1152.

6. Fomsgaard, A., M. Svenson, and K. Bendtzen. 1989. Auto-antibodies to tumour necrosis factor $\alpha$ in healthy humans and patients with inflammatory diseases and Gram-negative bacterial infections. Scand. J. Immunol. 30:219-223.

7. Ross, C., M. B. Hansen, T. Schyberg, and K. Berg. 1990. Autoantibodies to crude human leucocyte interferon (IFN), native human IFN, recombinant human IFN- $\alpha 2 b$ and human IFN- $\gamma$ in healthy blood donors. Clin. Exp. Immunol. 82:57-62.

8. Caruso, A., C. Bonfanti, D. Colombrita, M. de Francesco, C. de Rango, I. Foresti, F. Gargiulo, R. Gonzales, G. Gribaudo, S. Landolfo, N. Manca, G. Manni, F. Pirali, P. Pollara, G. Ravizzola, G. Scura, L. Terlenghi, E. Viani, and A. Turano. 1990. Natural antibodies to IFN- $\gamma$ in man and their increase during viral infection. J. Immunol. 144:685-690.

9. Leusch, H.-G., G. Sitzler, and S. Markos-Pusztai. 1991. Failure to demon- strate TNF $\alpha$-specific autoantibodies in human sera by ELISA and Western blot. J. Immunol. Methods. 139:145-147.

10. Ikeda, Y., G. Toda, N. Hashimoto, N. Umeda, K. Miyake, M. Yamanaka, and K. Kurokowa. 1991. Naturally occurring anti-interferon- $\alpha 2 \mathrm{a}$ antibodies in patients with acute viral hepatitis. Clin. Exp. Immunol. 85:80-84.

11. Figlin, R. A., and L. M. Itri. 1988. Anti-interferon antibodies: A perspective. Sem. Hematol. 25(Suppl. 3):9-15.

12. Mae, N., D. J. Liberato, R. Chizzonite, and H. Satoh. 1991. Identification of high-affinity anti-IL- $1 \alpha$ autoantibodies in normal human serum as an interfering substance in a sensitive enzyme-linked immunosorbent assay for IL- $1 \alpha$. Lym phokine Cytokine Res. 10:61-68.

13. Hansen, M. B., M. Svenson, M. Diamant, and K. Bendtzen. 1991. Antiinterleukin-6 antibodies in normal human serum. Scand. J. Immunol. 33:777781.

14. Hansen, M. B., M. Svenson, M. Diamant, and K. Bendtzen. 1993. Highaffinity $\mathrm{IgG}$ autoantibodies to IL-6 in sera of normal individuals are competitive inhibitors of IL-6 in vitro. Cytokine. 5:72-80.

15. Thurmond, L. M., and M. J. Reese. 1991. Immunochemical characterization of human antibodies to lymphoblastoid interferon. Clin. Exp. Immunol. 86:514-519.

16. DeForge, L. E., and D. G. Remick. 1991. Sandwich ELISA for detection of picogram quantities of interleukin-8. Immunol. Invest. 20:89-97.

17. Mogensen, K. E., P. H. Daubas, I. Gresser, D. Sereni, and B. Varet. 1981. Patient with circulating antibodies to $\alpha$-interferon. Lancet. 2:1227-1228.

18. Bost, K. L., B. H. Hahn, M. S. Saag, G. M. Shaw, D. A. Weigent, and J. E. Blalock. 1988. Individuals infected with HIV possess antibodies against IL-2. Immunology. 65:611-615.

19. Svenson, M., L. K. Poulsen, A. Fomsgaard, and K. Bendtzen. 1989. IgG autoantibodies against interleukin $1 \alpha$ in sera of normal individuals. Scand. $J$. Immunol. 29:489-492.

20. Svenson, M., M. B. Hansen, and K. Bendtzen. 1990. Distribution and characterization of autoantibodies to interleukin $1 \alpha$ in normal human sera. Scand. J. Immunol. 32:695-701.

21. Saurat, J.-H., J. Schifferli, G. Steiger, J.-M. Dayer, and L. Didierjean. 1991. Anti-interleukin- $1 \alpha$ autoantibodies in humans: Characterization, isotype distribution, and receptor-binding inhibition-Higher frequency in Schnitzler's syndrome (urticaria and macroglobulinemia). J. Allergy Clin. Immunol. 88:244-256

22. Suzuki, H., T. Ayabe, J. Kamimura, and H. Kashiwagi. 1991. Anti-IL-1 $\alpha$ autoantibodies in patients with rheumatic diseases and in healthy subjects. Clin. Exp. Immunol. 85:407-412.

23. Sunder-Plassmann, G., P. L. Sedlacek, R. Sunder-Plassmann, K. Derfler, K. Swoboda, V. Fabrizii, M. M. Hirschl, and P. Balcke. 1991. Anti-interleukin$1 \alpha$ autoantibodies in hemodialysis patients. Kidney Int. 40:787-791.

24. Vallbracht, A., J. Treuner, B. Flehmig, K. E. Joester, and D. Niethammer. 1981. Interferon-neutralizing antibodies in a patient treated with human fibroblast interferon. Nature (Lond.). 289:496-497.

25. Panem, S., I. J. Check, D. Henriksen, and J. Vilcek. 1982. Antibodies to $\alpha$-interferon in a patient with systemic lupus erythematosus. J. Immunol. 129:13.

26. Trown, P. W., M. J. Kramer, R. A. Dennin, E. V. Connell, and A. V. Palleroni. 1983. Antibodies to human leucocyte interferons in cancer patients. Lancet. 1:81-87.

27. Suzuki, H., T. Akama, M. Okane, I. Kono, Y. Matsui, K. Yamane, and H. Kashiwagi. 1989. Interleukin-1-inhibitory IgG in sera from some patients with rheumatoid arthritis. Arthritis Rheum. 32:1528-1538.

28. Larrick, J. W. 1989. Native interleukin 1 inhibitors. Immunol. Today. 10:61-66.

29. Lantz, M., U. Gullberg, E. Nilsson, and I. Olsson. 1990. Characterization in vitro of a human tumor necrosis factor-binding protein. A soluble form of a tumor necrosis factor receptor. J. Clin. Invest. 86:1396-1342.

30. Capper, S. J., S. Kalinka, and T. H. Mander. 1990. Specific radioimmunoassays for IL $1 \alpha$ and IL $1 \beta$ in plasma at physiological and acidic pH: Determination of immunoreactive forms by gel filtration and radioligand binding studies. Cytokine. 2:182-189.

31. Hansen, M. B., M. Svenson, and K. Bendtzen. 1992. Serum-induced suppression of interferon (IFN) activity. Lack of evidence for the presence of specific autoantibodies to IFN- $\alpha$ in normal human sera. Clin. Exp. Immunol. 88:559-562.

32. Fuhlbrigge, R. C., K. C. F. Sheehan, R. D. Schreiber, D. D. Chaplin, and E. R. Unanue. 1988. Monoclonal antibodies to murine IL- $1 \alpha$. Production, characterization, and inhibition of membrane-associated IL-1 activity. J. Immunol. 141:2643-2650.

33. Möller, A., F. Emling, D. Blohm, E. Schlick, and K. Schollmeier. 1990. Monoclonal antibodies to human tumor necrosis factor $\alpha$ : In vitro and in vivo application. Cytokine. 2:162-169.

34. Hogquist, K. A., M. A. Nett, K. C. F. Sheehan, K. D. Pendleton, R. D. Schreiber, and D. D. Chaplin. 1991. Generation of monoclonal antibodies to murine IL-1 $\beta$ and demonstration of IL-1 in vivo. J. Immunol. 146:1534-1540.

35. Svenson, M., M. B. Hansen, L. Kayser, Å. K. Rasmussen, C. M. Reimert, 
and K. Bendtzen. 1992. Effects of human anti-IL-1 $\alpha$ autoantibodies on receptor binding and biological activities of IL-1. Cytokine. 4:125-133.

36. Morgan, C. D., K. C. Mills, D. L. Lef kowitz, and S. S. Lef kowitz. 1991. An improved colorimetric assay for tumor necrosis factor using WEHI 164 cells cultured on novel microtiter plates. J. Immunol. Methods. 145:259-262.

37. Bendtzen, K., M. B. Hansen, M. Diamant, P. Heegaard, and M. Svenson. 1992. Cytokine regulation during inflammation: modulation by autoantibodies and fever. In Neuro-Immunology of Fever. T. Bartfai and D. Ottoson, editors. Pergamon Press, Oxford. 215.

38. Tankersley, D. L., M. S. Preston, and J.S. Finlayson. 1988. Immunoglobulin G dimer: an idiotype-anti-idiotype complex. Mol. Immunol. 25:41-48.

39. Moonen, P., R. Gaffner, and P. Wingfield. 1988. Native cytokines do not bind to uromodulin (Tamm-Horsfall glycoprotein). FEBS (Fed. Eur. Biochem Soc.) Lett. 226:314-318.

40. Roux, K. H., and D. L. Tankersley. 1990. A view of the human idiotypic repertoire. Electron microscopic and immunologic analyses of spontaneous idiotype-anti-idiotype dimers in pooled human IgG. J. Immunol. 144:1387-1395.

41. Harlow, E., and D. Lane. 1988. Antibodies. A laboratory manual. Cold Spring Harbor Laboratory Press, Cold Spring Harbor, NY. 496 pp.

42. Batteiger, B. E. 1988. Blocking of immunoblots. In CRC Handbook of Immunoblotting of Proteins. Vol I. Technical Descriptions. O. J. Bjerrum and N. H. H. Heegaard, editors. CRC Press, Boca Raton, FL, USA. 145.

43. Jones, E. Y., D. I. Stuart, and N. P. C. Walker. 1989. Structure of tumour necrosis factor. Nature (Lond.). 338:225-228.

44. Petersen, C. M., A. Nykjær, B. S. Christiansen, L. Heickendorff, S. C Mogensen, and B. Moller. 1989. Bioactive human recombinant tumor necrosis factor- $\alpha$ : an unstable dimer? Eur. J. Immunol. 19:1887-1894.
45. Schoenfeld, H.-J., B. Poeschl, J. R. Frey, H. Loetscher, W. Hunziker, A Lustig, and M. Zulauf. 1991. Efficient purification of recombinant human tumor necrosis factor $\beta$ from Escherichia coli yields biologically active protein with a trimeric structure that binds to both tumor necrosis factor receptors. J. Biol Chem. 266:3863-3869.

46. Breen, E. C., A. R. Rezai, K. Nakajima, G. N. Beall, R. T. Mitsuyasu, T. Hirano, T. Kishimoto, and O. Martinez-Maza. 1990. Infection with HIV is associated with elevated IL-6 levels and production. J. Immunol. 144:480-484.

47. Eastgate, J. A., J. A. Symons, N. C. Wood, S. J. Capper, and G. W. Duff. 1991. Plasma levels of interleukin-1-alpha in rheumatoid arthritis. Br. J. Rheu matol. 30:295-297.

48. Mahida, Y. R., L. Kurlac, A. Gallagher, and C. J. Hawkey. 1991. High circulating concentrations of interleukin- 6 in active Crohn's disease but not ulcerative colitis. Gut. 32:1531-1534.

49. Damas, P., D. Ledoux, M. Nys, Y. Vrindts, D. De Groote, P. Franchimont, and M. Lamy. 1992. Cytokine serum level during severe sepsis in human IL-6 as a marker of severity. Ann. Surg. 215:356-362.

50. Starnes, H. F., Jr., M. K. Pearce, A. Tewari, J. H. Yim, J. C. Zou, and J. S. Abrams. 1990. Anti-IL-6 monoclonal antibodies protect against lethal Esche richia coli infection and lethal tumor necrosis factor- $\alpha$ challenge in mice. $J$. Immunol. 145:4185-4191.

51. Jesmok, G., C. Lindsey, M. Duerr, M. Fournel, and T. Emerson, Jr. 1992 Efficacy of monoclonal antibody against human recombinant tumor necrosis factor in E. coli-challenged swine. Am. J. Pathol. 141:1197-1207.

52. Weaver, C. T., and E. R. Unanue. 1990. The costimulatory function of antigen-presenting cells. Immunol. Today. 11:49-55. 